\title{
Filozofia zrównoważonego rozwoju a realizacja jej postulatów w praktyce społecznej
}

\author{
Zbigniew Hull \\ Uniwersytet Warmińsko-Mazurski w Olsztynie \\ ul. Michała Oczapowskiego 2, 10-719 Olsztyn \\ zhull@wp.pl
}

\section{Streszczenie}

Pogłębiający się globalny kryzys ekologiczny prowokuje do postawienia pytania o praktyczną skuteczność postulatów formułowanych na gruncie filozofii zrównoważonego rozwoju. Podejmując próbę odpowiedzi na to pytanie, wyszedłem z założenia, że filozofia zrównoważonego rozwoju jest filozofią polityczną, która w sferze życia społeczno-gospodarczego funkcjonuje jako modna/obowiązująca ideologia, aprobowana i postulowana przez dominujące dziś w świecie siły polityczne i wielki biznes. Konfrontując, w skali zglobalizowanej ludzkości, głoszone hasła i deklaracje z praktyką polityczną i funkcjonowaniem światowej gospodarki, doszedłem do wniosku, że dotychczasowe działania zmierzające do realizacji idei zrównoważonego rozwoju w niewielkim tylko stopniu przyczyniły się do zmniejszenia zagrożeń globalną katastrofą ekologiczną. De facto stanowią one swoistą „zasłonę dymną” dla biznesu i polityków, którzy w realnych działaniach kontynuują dotychczasowy, nakierowany na ciągły wzrost konsumpcji i PKB kierunek rozwoju cywilizacyjnego. Ukazuje to, że filozofia zrównoważonego rozwoju jest już praktycznie nieskuteczna, nie jest dziś w stanie teoretycznie sprostać wyzwaniom, przed jakimi staje ludzkość w XXI w.

\section{Słowa kluczowe}

ekofilozofia, zrównoważony rozwój, zglobalizowana ludzkość, samozagłada

\section{Wstęp}

Twórca biogeochemii, rosyjski uczony Włodzimierz Wiernadski, już w latach 30. XX w. sformułował tezę, że wraz z pojawieniem się ludzkich cywilizacji rozpoczęła się nowa era w historii Ziemi - „antropogenna era geologiczna” (Wiernadski 1977: 28). Choć trwają dyskusje dotyczące szczegółowego określenia cech definicyjnych tej - nazwanej dziś antropocenem - ery (Bińczyk 2018), to przekonanie, że ludzkie oddziaływania na biogeofizyczne parametry (określające i zapewniające istniejącą dynamiczną równowagę Ziemi jako systemu) w istotny sposób zakłócają obecną homeostazę biosfery, homeostazę umożliwiającą istnienie ewolucyjnie ukształtowanych form życia w ich obecnym kształcie i stawiają pod znakiem zapytania dalszy rozwój ludzkich cywilizacji. Szósta katastrofa (szybkie i masowe wymieranie gatunków) w historii ewolucji życia na Ziemi, proces globalnej zmiany klimatu i związane z tym zmiany fizycznych i chemicznych charakterystyk oceanu 
światowego oraz olbrzymich obszarów lądowych, zanieczyszczanie i degradacja środowiska w skali globalnej, wyczerpywanie się zasobów surowcowych i energetycznych niezbędnych dla kontynuowania dotychczasowego modelu rozwoju cywilizacyjnego to niezaprzeczalne dziś fakty i procesy świadczące o geologicznej skali i mocy działania człowieka na naszej planecie. W efekcie swej własnej aktywności ludzkość znalazła się w ekologicznym punkcie zwrotnym i stanęła w obliczu biologicznej samozagłady. Wiemy o tym już od czasów ukazania się słynnego, pierwszego raportu dla Klubu Rzymskiego Granice wzrostu, którego podstawowe tezy i dziś są aktualne. W podtekście, ukryciu mamy także, poczynając od lat 50. XX w., możliwość czy perspektywę samozagłady atomowej powstrzymywanej strategią równowagi strachu. Poczynając zaś od początku XXI w., coraz głośniej i częściej mówi się o zagrożeniach związanych z rozwojem najnowszych technologii, zwłaszcza z rozwojem sztucznej inteligencji i biotechnologii wraz z ich wzajemnym powiązaniem.

Wszystko to sprawia, że - a dodać do tego trzeba permanentne konflikty i kryzysy społeczne i polityczne - zasadna jest teza o globalnym kryzysie ludzkości przejawiającym się we wszystkich sferach rozwoju cywilizacyjnego. W relacjach człowieka z przyrodą nastąpiło bowiem "rozdarcie metaboliczne" (metabolic rift) $)^{1}$, czyli rozejście się społecznego procesu korzystania z przyrody, użytkowania i przetwarzania jej zasobów w dążeniu do zaspokajania rosnących i różnorodnych potrzeb (w dobie współczesnego, globalnego kapitalizmu sprowadzonych do maksymalizacji konsumpcji, zysku, wzrostu gospodarczego itp.) z naturalnymi/przyrodniczymi/biologicznymi warunkami i podstawami istnienia społeczności ludzkich. Jeśli

1 Szerzej na temat rozumienia tego określenia w kontekście kryzysu współczesnego, neoloberalnego kapitalizmu pisze E. Bińczyk w książce Epoka człowieka. Retoryka i marazm antropocenu (s. 155-158). w dotychczasowej historii społeczności te ${ }^{2}$, dzięki nauce i technice, radziły sobie z lokalnymi kryzysami ekologicznymi i katastrofami naturalnymi, to dzisiaj mamy do czynienia z jakościowo nową sytuacją: dzisiaj zglobalizowana ludzkość zmienia Ziemię i funkcjonujące na niej życie w globalnej skali, gospodarując przyrodą niezgodnie z zasadami ekologii. Historycznie ukształtowana ekonomia człowieka zderzyła się z ekonomią przyrody.

\section{Idea zrównoważonego rozwoju jako filozofia społeczno-polityczna}

Rozwijająca się od początku lat 7o. XX wieku ekofilozofia zmierza do całościowego ujęcia i zrozumienia tego nowego, globalnego i totalnego konfliktu między człowiekiem a przyrodą. Zarazem jej twórcy, propagatorzy i zwolennicy poszukują sposobów przezwyciężenia tego konfliktu i rozwiązania kryzysu ekologicznego, formułując różne propozycje zmian w wielu sferach życia społeczno-politycznego, edukacji, gospodarce itp. oraz wizje dalszego, respektującego wymogi ekologii, rozwoju cywilizacyjnego.

Jedną z takich wizji stała się (po opublikowaniu w 1987 r. raportu Światowej Komisji do Spraw Środowiska i Rozwoju ONZ - Nasza wspólna przyszłość 1991 - zwanego potocznie, od nazwiska przewodniczącej Komisji, Raportem Brundtland) idea sustainable development nazywana w Polsce ideą/koncepcją/zasadą zrównoważonego - niekiedy dodaje się jeszcze „i trwałego" - rozwoju. Zastąpiła ona rozważaną i propagowaną wcześniej na gruncie ekofilozofii ideę ekorozwoju (postulującą priorytet wymogów i kryteriów ekologicznych we wszystkich sferach ludzkiej działalności), wzbogacając i poszerzając wizję dalszego rozwoju cywilizacyjnego o dodatkowe wymiary: gospodarczy (ekonomiczny) i społeczno-polityczny oraz wprowadzając wymóg zrównoważenia i wzajemnego

2 Nie wszystkie badania historyków ujawniają przykłady samozagłady różnych społeczności i cywilizacji. (por. Diamond 2005). 
podtrzymywania się wszystkich wymiarów ludzkiej aktywności w procesie rozwoju. W sferze proponowanej aksjologii przyszłego rozwoju ma tu więc miejsce odchodzenie od dominacji wartości ekologicznych na rzecz postulatu równorzędności wartości ekologicznych, społeczno-politycznych i ekonomicznych.

Szeroko rozumiana i najczęściej hasłowo czy ogólnikowo formułowana przez organizacje pozarządowe, aktywistów samorządowych, polityków i sfery gospodarcze idea zrównoważonego rozwoju stała się także przedmiotem refleksji ekofilozoficznej. Nie wdając się w szczegółowe metafilozoficzne analizy, dotyczące teoretycznego statusu filozofii zrównoważonego rozwoju, można dziś wyróżnić trzy odrębne sposoby pojmowania tego określenia. Przez filozofię zrównoważonego rozwoju rozumie się zatem:

- powszechnie akceptowane, postulowane czy też najczęściej wymieniane założenia (tezy) filozoficzne (metafizyczne/ontologiczne, epistemologiczne, antropologiczne, aksjologiczne i historiozoficzne) leżące $u$ podstaw idei zrównoważonego rozwoju. Często nie wszystkie $\mathrm{z}$ tych założeń są formułowane explicite, tym niemniej można by pokusić się o zbudowanie w miarę pełnego i koherentnego systemu (koncepcji) filozoficznych podstaw zrównoważonego rozwoju, systemu pretendującego do roli teoretycznej podstawy i uzasadnienia dla społeczno-gospodarczej i politycznej praktyki wdrażania tej idei we współczesnym świecie;

- odrębne podejścia, określone i w miarę wyraźnie wyartykułowane filozoficzne koncepcje zrównoważonego rozwoju, z których każda pretenduje do najlepszego i właściwego ujęcia tej problematyki. Koncepcje te wprawdzie podzielają "paradygmatyczne” założenia wyjściowe idei zrównoważonego rozwoju, natomiast różnią się między sobą sięganiem do innych tradycji filozoficznych (przede wszystkim metafizycznych i antropologicznych), politycznych i - przede wszystkim - różnią się preferencjami aksjologicznymi między grupami wartości-celów i wartości-środków oraz w ramach tych grup ${ }^{3}$;

- „[...] względnie niezależną dyscyplinę filozoficzną [...] samodzielną subdyscyplinę filozoficzną" (Papuziński 2007: 27, 33) z wyodrębniającym się przedmiotem, własnym polem problemowym i „zasadami konstrukcji modelu rzeczywistości”. Tak rozumiana filozofia zrównoważonego rozwoju nie powinna być traktowana jako ,jeszcze jedna koncepcja ekofilozoficzna”, gdyż charakteryzuje ją „odmienny w stosunku do ekofilozofii charakter badań skoncentrowanych na zrównoważonym rozwoju jako współczesnej idei politycznej - idei jak najbardziej konkretnej, mającej swoją określoną genezę, wiadomych twórców i takie a nie inne zastosowanie w zakresie międzynarodowych i krajowych stosunków politycznych" (Papuziński 2007: 27).

Nie wdając się w dyskusje dotyczące wzajemnych relacji między ekofilozofią a filozofią zrównoważonego rozwoju, przyjmuję tu, zaproponowane przez A. Papuzińskiego, rozumienie filozofii zrównoważonego rozwoju jako filozofii dziś de facto politycznej, zarysowana bowiem przez niego problematyka tej sfery rozważań wykracza poza horyzont poznawczy ekofilozofii, choć nie stroni od pytań i kwestii ekofilozoficznych. Jest to naturalne i zrozumiałe, gdyż nie sposób uciec (czy ustrzec się) od filozofii (w tym przypadku - ekofilozofii), formułując założenia wyjściowe i projektując w kategoriach teoretycznych społeczno-polityczną interpretację idei zrównoważonego rozwoju. Jeśli bowiem dobrze odczytuję tekst i intencje A. Papuzińskiego, istota jego poglądów sprowadza się do przekonania,

3 Mam tu na myśli rozumienie tych pojęć wprowadzone przez A. Papuzińskiego w jego analizach dotyczących filozofii zrównoważonego rozwoju (Papuziński 2011: 114-115). 
że to co powszechnie nazywa się filozofią zrównoważonego rozwoju, posiada wszelkie znamiona projektu czy programu ideologicznego, koncentruje się bowiem na kwestiach polityki społeczno-gospodarczej, zasad organizowania i funkcjonowania biznesu, polityki społecznej, wewnętrznej i międzynarodowej, teorii i praktyki ochrony środowiska, propozycjach określonych działań politycznych, ekonomicznych, edukacyjnych itp. w kontekście obecnego kryzysu ekologicznego i - szerzej - cywilizacyjnego. Cywilizacyjnego, gdyż kryzys ekologiczny jest w istocie załamaniem się dotychczasowych sposobów cywilizacyjnego "organizowania natury”, łącznie z ludźmi w ich relacjach z przyrodą i między sobą. Jest więc filozofia zrównoważonego rozwoju de facto swoistym konglomeratem wizji historiozoficznej, filozofii społecznej i ideologii, u podstaw którego leżą, powtórzmy, określone założenia filozoficzne (ekofilozoficzne). Założenia te, $\mathrm{z}$ racji niedopracowania, czy tworzenia się dopiero tego projektu ideologicznego i programów jego realizacji, wybijają się na plan pierwszy, sprawiając wrażenie, że o filozofię tu chodzi. I faktycznie mamy tu do czynienia z filozofią społeczno-polityczną, która w odbiorze potocznym przyjmuje postać projektów ideologicznych bardzo różnie interpretujących tytułową ideę zrównoważonego rozwoju.

Wszystkie te projekty odwołują się do tych samych pojęć, ale już w punkcie wyjścia różnie je rozumieją, poczynając do tego, że często nie odróżniają pojęcia rozwoju od wzrostu. Tymczasem pojęcia te, choć treściowo są sobie bliskie, mają różne znaczenia. W odróżnieniu od „wzrostu”, który polega na „dodawaniu ilości” w obrębie danego układu (stałej struktury jakiegoś systemu), „rozwój” to proces przemian, w trakcie których zachodzi jakościowe (strukturalne czy/i funkcjonalne) przekształcanie się zachowującego tożsamość systemu w zmieniających się i różnicujących warunkach środowiska. Tak rozumiane pojęcie rozwoju stosuje się również do całościowo i szeroko rozumianego systemu społecznego (mówimy wtedy „rozwój cywilizacyjny” czy „rozwój społecznogospodarczy" itp.), którego podstawowymi dzisiaj elementami są: warunkujące istnienie i funkcjonowanie cywilizacji ludzkich środowisko przyrodnicze ze swoimi zasobami i biologicznymi uwarunkowaniami ludzkiej egzystencji - ludzie i struktury (więzi) społeczne - systemy wartości - struktury informacyjne - struktury techniczne - struktury gospodarcze - struktury polityczne. Przy czym wszystkie te elementy przenikają się wzajemnie, są ze sobą powiązane i oddziałują na siebie.

Również pojęcie zrównoważenia bywa różnie rozumiane: obok podkreślania konieczności równoważenia, sprawiedliwego potraktowania interesów i prawa do zaspokajania potrzeb i dobrego życia obecnego i przyszłych pokoleń (zrównoważenie jako wartość - równość możliwości, sprawiedliwość międzypokoleniowa), mówi się także (a niekiedy głównie) o równoważeniu jako o procesie uzgadniania, harmonizowania podstawowych wymiarów (elementów, ładów) składowych rozwoju cywilizacyjnego: przyrodniczego, gospodarczego, społeczno- politycznego, technologiczno-naukowego i świadomościowego (aksjologicznego). Przy czym w nieuniknionych sytuacjach konfliktu między nimi dla jednych najważniejszy jest rozwój gospodarczy, jako podstawa dobrobytu i zaspokajania wszelkich potrzeb, drudzy preferują wartości społeczne, inni zaś wskazują na priorytetowy, bo egzystencjalnie podstawowy, charakter czynników ekologicznych (przyrodniczych). Wszyscy zaś zgodnie dodają, że rozwój ten winien być trwały. Pojęcie „trwałości” - jak wskazuje Tadeusz Borys - „nie ma charakteru uniwersalnego, lecz jest stopniowalne według «surowości», czy restrykcyjności zasady zachowania kapitału naturalnego" (Borys 2003: 72). Zwykle wyróżnia się cztery wersje zasady trwałości:

- $\quad$ słabą zasadę trwałości (zwaną też zasadą pełnej substytucji kapitałów), według której trwałość polega na zachowaniu wielkości całkowitego 
kapitału bez względu na jego strukturę. Inaczej mówiąc, przyjmuje się tu, że kapitał przyrodniczy może być zastępowany czy rekompensowany przez kapitał antropogenny;

- umiarkowaną zasadę trwałości (inaczej - ograniczonej substytucji) postulującą, by - zachowując całkowitą wielkość kapitału - wymagać, by wszystkie składowe kapitału zawsze w nim występowały oraz by określić ich wzajemne proporcje czy też minimalny udział w całości, gdyż kapitał przyrodniczy i kapitał wytworzony przez człowieka mogą być substytutami tylko w określonych granicach;

- $\quad$ silną zasadę trwałości (zwaną też zasadą komplementarności kapitałów), która - wychodząc z założenia, że kapitały przyrodniczy i antropogenny nie są względem siebie substytucyjne, lecz komplementarne - postuluje zachowanie każdego z nich $\mathrm{z}$ osobna. $\mathrm{Z}$ zasady tej wynika, że warunkiem rozwoju jest niedopuszczenie do istotnego, z punktu widzenia równowagi ekosystemów i funkcjonowania biosfery, ubytku ilości i jakości dóbr i usług środowiska przyrodniczego;

- restrykcyjną zasadę trwałości (określaną niekiedy jako bardzo silną) rozumie się jako zakazującą uszczuplania któregokolwiek z kapitałów. Zgodnie z nią zasoby nieodnawialne, wchodzące w skład kapitału przyrodniczego, w zasadzie nie powinny być eksploatowane, w odniesieniu zaś do zasobów odnawialnych dopuszczalne jest użycie tylko tej ich części, która jest ich rocznym przyrostem i nie wpłynie na zdolność do odnawiania się tego zasobu (Borys 2003: 72-73).

Niekiedy w literaturze przedmiotu można spotkać uproszczone wyróżnienie tylko dwóch podstawowych zasad: słabej (włączającej wymienioną tu umiarkowaną zasadę trwałości) i mocnej (wykluczającą de facto zasadę restrykcyjną).

\section{Wielowymiarowość zrównoważonego rozwoju}

Najczęściej idea zrównoważonego rozwoju analizowana i interpretowana jest $\mathrm{w}$ kategoriach ekonomicznych - jako obecnie najlepszy pomysł na przezwyciężenie globalnego kryzysu społeczno-gospodarczego i ekologicznego. Ujęcia te już w definicjach podkreślają priorytet wzrostu/rozwoju gospodarczego, np. „Zrównoważony rozwój [...] to wskazana społecznie, celowa ekonomicznie i pożądana ekologicznie strategia rozwoju gospodarczego" (Leśniak 2009: 102-103) i standardowo wskazują, że tak rozumiany rozwój powinien realizować trzy grupy celów: ekonomiczne - wzrost PKB zapewniający odpowiednią i pożądaną ilość dóbr i usług, społeczne - zaspokajanie podstawowych potrzeb społecznych, ograniczanie bezrobocia, podnoszenie jakości życia itp., ekologiczne - poprawa stanu środowiska, zachowanie kapitału przyrodniczego koniecznego dla wzrostu gospodarczego, podtrzymanie produktywności ekosystemów i ochrona bioróżnorodności. Jeszcze większy nacisk na gospodarcze aspekty rozwoju zrównoważonego kładą w swej definicji D. Pearce i R.K. Turner, pisząc: „polega on na maksymalizacji korzyści netto z rozwoju ekonomicznego, chroniąc jednocześnie oraz zapewniając odtwarzanie się użyteczności i jakości zasobów naturalnych w długim okresie. Rozwój gospodarczy musi wówczas oznaczać nie tylko wzrost dochodów per capita, ale także poprawę innych elementów dobrobytu społecznego. Musi on obejmować również niezbędne zmiany strukturalne w gospodarce, jak i w całym społeczeństwie" (Kiełczewski 2008: 30). I takie podejście - koncentrujące się na wymiarze ekonomicznym, które możliwość i perspektywy zrównoważonego rozwoju upatruje we wzroście gospodarczym i większym dobrobycie, oraz postulat wprowadzenia mechanizmów rynkowych umożliwiających zyskowność „ekologizacji” gospodarki - dominuje wśród ekonomistów środowiska, w kręgach biznesu i polityków. Wprawdzie zwykle pisze się też o ekologicznych 
i społecznych celach rozwoju, to pozostaje jednak nieodparte wrażenie, iż ich realizacja jest niezbędna dla zapewnienia przyrodniczych i społeczno-politycznych warunków dalszego rozwoju cywilizacyjnego i możliwa tylko dzięki ich urynkowieniu. Dobitnym tego przykładem jest hasło "zielonego wzrostu" upowszechniane od czasu konferencji w Rio (2012).

Idea zrównoważonego rozwoju na dobre zagościła także w polityce, urastając do rangi centralnej kategorii teoretycznej i nośnego hasła w ramach tzw. polityki ekologicznej i zastępując dotychczasową politykę ochrony środowiska. Począwszy od słynnego już raportu Nasza wspólna przyszłość (1987) komisji ONZ pod przewodnictwem byłej premier Norwegii, Gro Harlem Bruntland, a w szczególności po głośnym Szczycie Ziemi w 1992 r. $\mathrm{w}$ Rio de Janeiro, termin sustainable development wszedł na stałe do języka polityki, debat publicznych, oficjalnych dokumentów ONZ, Unii Europejskiej, Konstytucji Rzeczypospolitej Polskiej („Rzeczpospolita Polska [...] zapewnia ochronę środowiska, kierując się zasadą zrównoważonego rozwoju", art. 5), programów rozwojowych organów rządowych i samorządowych wszystkich szczebli. Jednakże jego rozumienie jest bardzo różne, niekiedy z kontekstu dokumentu czy wypowiedzi wynika, że jest ono de facto sprowadzane do ochrony środowiska, ekologizacji gospodarki, zrównoważenia wzrostu gospodarczego, produktywności, ekoefektywności itp. (Haliniak 2008: 164-199). Często można też odnieść wrażenie, iż określenie to funkcjonuje w różnych wypowiedziach w charakterze obowiązującego ozdobnika, gdyż wszyscy, oczywiście, są za zrównoważonym rozwojem, ale nie kosztem wzrostu gospodarczego. Analizując dokumenty Komisji Europejskiej przygotowane na wiosenny (w 2008 r.) szczyt UE, M. Haliniak stwierdza: „W ramach oceny śródokresowej dotychczasowych postępów we wdrażaniu strategii lizbońskiej i wyznaczaniu kierunków dalszych działań na następne pięć lat uznano [...], że należy zrezygnować z filaru społecznego i ekologicznego [zrównoważonego rozwoju, Z.H.] na rzecz wzrostu gospodarczego i walki z bezrobociem" (Haliniak 2008: 199). Polskim przykładem takiego rozmijania się praktyki polityczno-gospodarczej z werbalnymi deklaracjami akceptacji idei zrównoważonego rozwoju są działania polskich polityków zmierzające do „wytargowania” w Komisji Europejskiej zmniejszenia kwot emisji $\mathrm{CO}_{2}$ przy jednoczesnych zaniedbaniach w przestawianiu energetyki na odnawialne i mało emisyjne źródła energii.

Można by wręcz powiedzieć, iż idea zrównoważonego rozwoju zyskała już powszechną akceptację, słowo „zrównoważenie" stało się dziś modne w środowiskach wszelkiego biznesu, polityków, menagerów, samorządowców, dziennikarzy: dziś wszystko ma, czy powinno być, zrównoważone - i to nie tylko w kontekście globalnie rozumianego rozwoju cywilizacyjnego, lecz także w każdej prawie skali i sferze ludzkiej aktywności. Pisze się więc o zrównoważonej gospodarce, konsumpcji, polityce społecznej, demografii, energii itp., zrównoważonym społeczeństwie, kapitalizmie, transporcie, budownictwie, żywieniu, rodzinie itd. I niezależnie od tego, jak kto rozumie zrównoważony rozwój - określenie to stało się już dzisiaj swoistą instytucja pojęciowa (Latour 2009: 161). Pisze się o zasadach, projektach, programach, edukacji dla zrównoważonego rozwoju itd. itp.

A co rzeczywiście się robi, jak wygląda realna praktyka wdrażania deklarowanych zasad w życiu społecznym?

\section{Globalna klęska praktyki wdrażania zrównoważonego rozwoju}

Praktykę społeczną rozumiem tu w sensie węższym, mając na myśli wszelkie ludzkie działania i struktury tworzące materialne i społeczne warunki i możliwości wymiany materii i przepływu energii między przyrodą a społeczeństwem, określające i umożliwiające istnienie i funkcjonowanie społeczności ludzkich i rozwój cywilizacyjny. Desygnatami tak pojmowanej praktyki są więc struktury przedmiotowe (materialne i społeczne) 
oraz decyzje i działania społeczne i indywidualne warunkujące i konstytuujące cywilizacyjne organizowanie natury i metabolizm społeczny, natomiast - w kontekście tematu rozważań - wyłączam z jej zakresu sferę teorii, "praktyki teoretycznej" 4 .

Idea zrównoważonego rozwoju odnoszona jest dziś zarówno do różnych sfer ludzkiej aktywności, terytoriów, państw, jak i do rozwoju cywilizacyjnego analizowanego w skali globalnej. Traktując ludzkość w jej relacjach z przyrodą jako zbiór różnorodnych elementów, które winny funkcjonować zgodnie z zasadami zrównoważonego rozwoju (jako zbiór w sensie dystrybutywnym), należałoby najpierw zbadać, czy zasady te mogą/powinny być respektowane/ stosowane we wszystkich sferach i dziedzinach ludzkiej praktyki społecznej w obecnej sytuacji globalnego kryzysu ekologicznego. Myślę, że nie, gdyż w wielu przypadkach zakres degradacji środowiska i zagrożenia katastrofami ekologicznymi (globalne ocieplenie, wymieranie gatunków, degradacja oceanu światowego, dewastacja i fragmentacja lądowych biocenoz) są tak zawansowane, iż nawoływanie do zrównoważonego rozwoju niewiele już pomoże. Mam tu na myśli działania dotyczące pozyskiwanie energii niezbędnej dla rozwoju, uzgadnianie emisji gazów cieplarnianych, eksploatację żywych zasobów światowego oceanu, pozyskiwanie/ produkcję i dystrybucję żywności czy gatunkową ochronę żywych zasobów przyrody. Tu „równoważenie" nie zatrzyma biegu ku katastrofie - tu konieczne jest respektowanie zasad ekologii i bezwzględny priorytet kryteriów ekologicznych w działaniu.

4 Czynię tak dla uproszczenia obrazu i uwypuklenia wymowy tezy referatu. Bo choć nie ma praktyki społecznej/działania bez jakiejś teorii (wytworzonej w procesie „praktyki teoretycznej”), to sama, nawet najlepiej pomyślana i opracowana teoria, nie ustanawia rzeczywistości. By tak się stało, konieczna jest nie tylko akceptacja teorii, lecz przede wszystkim silna/zniewalająca motywacja do działania, odpowiednie struktury i instytucje umożliwiające wcielenie jej w życie i samo to działanie (praktyka społeczna).
Natomiast w tych sferach i obszarach ludzkiej aktywności, w których nawoływanie do zrównoważonego rozwoju ma jeszcze sens (mam tu na myśli przede wszystkim biznes i wszelką działalność gospodarczą, masową konsumpcję dóbr materialnych, politykę wewnętrzną i międzynarodową, funkcjonowanie samorządów, społeczności lokalnych itp.), trudno mówić o postępie we wdrażaniu w życie zasad zrównoważonego rozwoju. Owszem, głosi się hasła „zrównoważenia”, wpisuje zasadę zrównoważonego rozwoju do konstytucji i innych aktów prawnych, zwołuje konferencje, podejmuje lokalne działania naprawcze, rozwija edukację ekologiczną czy prowadzi rozliczne działania na rzecz ochrony, rekultywacji środowiska, realizuje lokalne projekty przestawiania gospodarki na korzystanie $\mathrm{z}$ odnawialnych źródeł energii itp., ale nie ma to większego znaczenia dla przezwyciężenia globalnego kryzysu ekologicznego. Nie zmniejsza to w znaczący/istotny sposób zagrożenia globalną katastrofą ekologiczną w wyniku ocieplenia klimatu i wynikających z tego konsekwencji dla biosfery. W zglobalizowanej bowiem gospodarce i finansach nadal obwiązuje zasada business as usual, rozwojem cywilizacyjnym zglobalizowanej ludzkości rządzi gospodarka rynkowa, dążenie do maksymalizacji zysku i wzrostu PKB, trybalizm i nacjonalizm $\mathrm{w}$ relacjach i interakcjach między państwami oraz w działaniach zmierzających do ustanawiania nowego ładu światowego.

Po prostu dziś nie wystarczy już „myśleć globalnie i działać lokalnie”, suma nawet najlepiej zrealizowanych sektorowych i lokalnych projektów zrównoważonego rozwoju, nie „złoży” się w całość harmonijnego i trwałego rozwoju, dziś konieczne stają się uzgodnione i zsynchronizowane globalne działania przekraczające granice państwowe, antagonizmy społeczne, różnice religijne i światopoglądowe, uprzedzenia kulturowe itp. A tymczasem już pobieżna analiza tego wszystkiego, co dzieje się na świecie - doniesień środków masowej informacji, wypowiedzi polityków, przedstawicieli gospodarki i biznesu, większości przywódców 
religijnych, prezydentów, wszelakich kręgów wojskowych, a także większości tzw. przeciętnych obywateli - wyraźnie wskazuje, że wszyscy oni myślą w kategoriach mitycznie rozumianej suwerenności państwa, partykularnie pojmowanego interesu narodowego, mocarstwowych aspiracji, maksymalizacji zysku, konsumpcji i wzrostu PKB.

Jeśli spojrzeć na realizację idei zrównoważonego rozwoju w odniesieniu do zglobalizowanej ludzkości, rozumianej jako bio-społeczna całość (pojmowanej jako zbiór w sensie kolektywnym) w jej relacjach i interakcjach z przyrodą, to - poza konsekwentną realizacją Protokołu Montrealskiego - żadne z międzynarodowych/ globalnych ustaleń dotyczących zmniejszenia antropopresji na środowisko przyrodnicze nie zostało zrealizowane. Wprawdzie zwołuje się międzynarodowe i światowe konferencje dotyczące ograniczenia emisji gazów cieplarnianych, zanieczyszczenia światowego oceanu, ochrony żywych zasobów biosfery itp., podejmuje się i ratyfikuje stosowne uchwały, ale później są one realizowane wybiórczo bądź wcale, w ostatnich zaś latach dominuje marazm klimatyczny i denializm ${ }^{5}$ (Bińczyk 2018: 47-77). Politycy podejmują decyzje i działania z myślą o najbliższych wyborach, biznes dąży tylko do „cięcia kosztów”, wzrostu stopy zysku i pokonania konkurencji, „przeciętni obywatele” rozwiniętych/bogatych krajów chcą jeszcze większego dobrobytu i maksymalizacji konsumpcji, mieszkańcy zaś biednego południa chcą po prostu przeżyć i dołączyć do bogatych.

Obserwując i oceniając procesy zachodzące dziś w świecie przez pryzmat egzystencjalnych interesów gatunku homo sapiens, czyli z perspektywy możliwości przeżycia w warunkach globalnego ocieplenia i dalszego istnienia zglobalizowanej ludzkości, wyraźnie widać, że idea zrównoważonego rozwoju - choć funkcjonuje w charakterze obowiązującego

5 Przez denializm rozumiem tu strategie ignorowania, zaprzeczania i wypierania problemu. czy dyżurnego sloganu - stanowi zasłonę dymną, za którą kryją się mocarstwowe i korporacyjne interesy, dążenia do dominacji, imperializm gospodarczy, mitomania suwerenności państwowej czy lokalnej/ regionalnej, propaganda wyborcza itp. Nie dziwi więc, że coraz częściej zaczyna się mówić o „wyczerpywaniu się paradygmatu zrównoważonego rozwoju" (Bińczyk 2018: 173-18o) i postuluje konieczność wypracowania nowej wizji rozwoju cywilizacyjnego odwołującego się do "nieograniczonych” możliwości postępu naukowo-technicznego, który umożliwi dostosowanie ludzkości do globalnych zmian klimatu.

\section{Zakończenie}

Dotychczasowe działania zmierzające do realizacji idei zrównoważonego rozwoju tylko w niewielkim stopniu przyczyniły się do eliminacji zagrożenia globalną katastrofą ekologiczną. W ocenie przytłaczającej większości kompetentnych badaczy nie można już dziś kwestionować procesu zmiany klimatu, dyskusyjną pozostaje kwestia, czy przekroczyliśmy już point of no return, punkt graniczny, po którym zmian klimatu nie da się już zatrzymać i cofnać, co najwyżej można próbować je hamować, modyfikować i przystosowywać się do nich. Dlatego kontynuowanie dotychczasowego modelu rozwoju cywilizacyjnego musi doprowadzić do takich globalnych zmian klimatu, które $\mathrm{w}$ istotny sposób zmienią warunki istnienia i funkcjonowania życia na Ziemi. Kwestią otwartą jest, czy w tych zmienionych warunkach będzie możliwe istnienie gatunku homo sapiens i rozwój cywilizacyjny. Kolejne pytanie to: czy, jak i w jakim zakresie można zahamować proces zmiany klimatu. W obu tych kwestiach padają różne odpowiedzi, dominuje jednak przekonanie, że jeśli nawet uda się ludzkości spowolnić i zahamować obecny proces ocieplania Ziemi, to przywracanie klimatu do stanu z połowy XX w. nie będzie już możliwe. Wielu zaś uczonych uważa, że ludzkość nieuchronnie zmierza ku ekologicznej katastrofie i dopiero wywołana zmianami środowiska przyrodniczego 
gwałtowna klęska populacyjna (masowa śmierć miliardów ludzi) może zmotywować tych, którzy przeżyją, do zmiany sposobów użytkowania przyrody i - jeśli i na ile to jeszcze będzie możliwe - stworzenia warunków umożliwiających istnienie i rozwój cywilizacji.

Co z tego wynika dla filozofii zrównoważonego rozwoju? Otóż myślę, że jej czas już minął, że w świetle globalnej klęski praktyki wdrażania wizji zrównoważonego rozwoju w życie w skali globalnej (a tylko urzeczywistniana w takiej skali miała ona sens i szanse zmienić relacje człowieka z przyrodą) filozofia ta ujawniła swoją niemoc w motywowaniu i stymulowaniu realnych zmian w procesie rozwoju cywilizacyjnego i tym samym nie jest w stanie odpowiedzieć na wyzwania, wobec których staje dziś ludzkość. Dziś potrzebna jest jakaś nowa, społeczna, polityczna wersja ekofilozofii - filozofia ratowania ludzkości, „alertu egzystencjalnego" - filozofii uwzględniającej także wyzwanie populacyjne, przed jakim stanęła dziś ludzkość.

\section{Aneks demograficzny}

W dyskusjach dotyczących przezwyciężania kryzysu ekologicznego, katastrofy klimatycznej i przyszłości ludzkości pomija się zwykle jedno z podstawowych, dla zrozumienia tych kwestii i poszukiwania rozwiązań narastających zagrożeń zagadnienie - problem gwałtownego wzrostu populacji ludzkich. Przemilcza się (zwracał na to uwagę dawno temu A. Naess) podstawowy fakt, że ludzi jest już zbyt dużo (i będzie jeszcze więcej) w relacji do ekologicznych możliwości biosfery zaspokojenia ich egzystencjalnych potrzeb i zapewnienia im dostatniego życia i ciągłego wzrostu konsumpcji. Jest tak, gdyż z ekologicznego punktu widzenia rozwój cywilizacyjny ograniczył/wyeliminował naturalne mechanizmy regulujące liczebność populacji ludzkich, postęp zaś moralny „uświęcił” życie ludzkie i wykluczył/ograniczył możliwości planowego i racjonalnego ingerowania w liczebność populacji. Ta olbrzymia ilość żyjących dziś na Ziemi ludzi neutralizuje i w jakimś sensie bezowocnymi czyni większość działań „ochroniarskich”, programy i działania na rzecz zrównoważonego rozwoju itp. Mało kto ma dziś odwagę głośno o tym mówić, a jeśli już podejmuje ten temat, to spotyka się $\mathrm{z}$ oburzeniem albo i z potępieniem (spotkało to wspomnianego wyżej A. Naessa). Sprawę „zamiata się pod dywan", licząc na to, że może jakoś sama się rozwiąże, załatwi to za nas przyroda, klęski żywiołowe, lokalne czy regionalne wojny traktowane przez nas jako „siła wyższa”, na którą nie mamy wpływu (i wtedy będziemy mieli czyste sumienie). Myślę jednak, że winniśmy zdać sobie sprawę z faktu, iż zglobalizowana ludzkość musi dziś zmierzyć się z tym problemem i tragicznym dylematem: zredefiniować pojęcia świętości, wartości i jakości życia oraz poświęcić pewne tradycyjne wartości humanistyczne w imię ratowania własnej gatunkowej egzystencji, czy też, konsekwentnie respektując te tradycyjne wartości, zmierzać ku samozagładzie.

\section{Bibliografia}

Bińczyk E., 2018, Epoka człowieka. Retoryka i marazm antropocenu, Wydawnictwo Naukowe PWN SA, Warszawa.

Borys T., 2003, Regionalne wskaźniki zrównoważonego rozwoju, w: Pawłowski A. (red.) Filozoficzne i społeczne uwarunkowania zrównoważonego rozwoju, wyd. Komitet Ochrony Środowiska PAN, Lublin.

Diamond J., 2005, Upadek. Dlaczego niektóre spoŁeczeństwa upadty a innym się udato, Prószyński i S-ka, Warszawa.

Haliniak M., 20o8, Filozofia polityki ekologicznej, Episteme nr 80.

Latour B., 2009, Polityka natury, Wydawnictwo Krytyki Politycznej, Warszawa.

Leśniak J., 2009, Koncepcja zrównoważonej konsumpcji, w: Kiełczewski D., Dobrzańska B (red.) Ekologiczne problemy zrównoważonego rozwoju, Wydawnictwo WSE w Białymstoku, Białystok.

Nasza wspólna przyszłość, 1991, Raport Światowej Komisji do Spraw Środowiska i Rozwoju PWE, Warszawa. 
Papuziński A., 2007, Filozofia zrównoważonego rozwoju jako subdyscyplina badań filozoficznych, „Problemy Ekorozwoju”, nr 2.

Papuziński A., 2011, Realizacja zrównoważonego rozwoju, „Problemy Ekorozwoju”, nr 1.
Pearce D., Turner R.K., Economics of Natural Resources and the Environment, Harvester Wheatsheaf, New York.

Wiernadski W.I., 1977, Razmyszlenija naturalista. Naucznaja myśl kak płanietnoje jawlenije, Izdatielstwo „NAUKA”, Moskwa.

\title{
The philosophy of sustainable development and the implementation of its postulates in social practice
}

\begin{abstract}
The deepening global ecological crisis raises a question about the practical effectiveness of postulates formulated based on the philosophy of sustainable development.

In attempting to answer this question, I assumed that the philosophy of sustainable development is a political philosophy, which functions in the sphere of socio-economic life as a fashionable/binding ideology, approved and postulated by the currently dominating political forces and large companies.

When I confronted, on the scale of globalised world, the slogans and declarations with political practice and the functioning of the world economy, I came to the conclusion that the current efforts to implement the idea of sustainable development have only slightly contributed to reducing the threat of a global ecological disaster.

In fact, they are a kind of 'smoke screen' for business and politicians, who in practice continue the existing course of civilisational development aimed at continuous growth of consumption and GDP.

This shows that the philosophy of sustainable development is already practically ineffective and is today not able to cope theoretically with the challenges facing humanity in the $21^{\text {st }}$ century.
\end{abstract}

\section{Keywords}

eco-philosophy, sustainable development, globalised humanity, self-destruction 